\title{
THE BACTERICIDAL ACTION OF HUMAN SERUM ON BACTEROIDES SPECIES
}

\author{
V. O. Rotimi AND P. I. EKE
}

Department of Microbiology and Parasitology, College of Medicine of University of Lagos, P.M.B. 12003, Idi-Araba, Lagos, Nigeria

SUmmaRY. Sera obtained from 60 healthy normal subjects were tested for their inhibitory action against four clinical isolates of the Bacteroides fragilis group. All the sera inhibited clinical strains of B.vulgatus and $B$. ovatus, $92 \%$ of 60 sera inhibited B. thetaiotaomicron and $62 \%$ inhibited $B$. fragilis. Bacterial inhibition required components of uninactivated serum and was related to the serum concentrations and species of the bacteria. The viable counts of all the strains, except $B$. fragilis, were significantly reduced in pooled sera from patients with anaerobic systemic infections and from non-infected patients. The bactericidal activity of the sera from infected patients was more pronounced than that of the 'normal' sera, on all strains except $B$. fragilis. These observations may explain in part the predominance of $B$. fragilis in serious clinical infections involving anaerobes.

\section{INTRODUCTION}

Anaerobic bacteria form the bulk of the normal bacterial flora of the oral cavity (particularly in the gingival crevice, dental plaque and interdental spaces), the gastrointestinal, female genital and respiratory tracts (Drasar, Shiner and McLeod, 1969; Duerden, 1980a; Rotimi and Duerden, 1981a; Masfari, Kinghorn and Duerden, 1983). In the last two decades Bacteroides spp. and anaerobic cocci have been increasingly implicated in a number of clinical infections, some of which were life-threatening (Sinkovics and Smith, 1970; Felner and Dowell, 1971; Bartlett and Finegold, 1972; Gorbach and Bartlett, 1974; Rotimi and Abudu, in press). B. fragilis, the type species of the $B$. fragilis group which includes $B$. thetaiotaomicron, $B$. vulgatus, $B$. fragilis, $B$. ovatus and $B$. distasonis, is the species most commonly isolated from human infections (Holland, Hill and Altemeier, 1977; Polk and Kasper, 1977; Duerden, 1980b). These anaerobes have often been regarded as opportunistic pathogens which express their pathogenic potential when the integrity of the host defence is breached.

However, little information is available on the specific host defence mechanisms. Roberts (1970) and Williams (1972) showed that the activities of the phagocytes, macrophages and polymorphonuclear leukocytes (PMN) were of paramount importance in the killing of facultative and aerobic bacteria. Some Bacteroides spp. are 
known to interfere with the phagocytosis of some facultative bacteria in vitro (Ingham et al., 1977). Faecal isolates of members of the B. fragilis group have been shown to be sensitive to the bactericidal action of normal human serum (Casciato et al., 1979) which is also enhanced by the presence of active PMN (Casciato et al., 1975). The work reported here was undertaken to study the susceptibility of clinical isolates of the $B$. fragilis group to normal human serum and to compare the viability of these clinical isolates in serum from patients with proven anaerobic infections with that in serum from non-infected controls.

\section{MATERIALS AND METHODS}

\section{Bacterial strains}

Four clinical isolates were used in the study: $B$. fragilis, isolated from a positive blood culture; $B$. vulgatus and $B$. thetaiotaomicron, isolated from post-surgical wound infections; and B. ovatus isolated from an infected ulcer in a patient with an underlying malignant lesion. All isolates were identified by the methods of Duerden et al. (1980) and Rotimi, Faulkner and Duerden (1980) and kept frozen in $1-\mathrm{ml}$ portions, as stock cultures, at $-70^{\circ} \mathrm{C}$. When needed they were grown on freshly prepared BM-Kanamycin agar (Holbrook, Ogston and Ross, 1978) and also inoculated on to blood agar incubated aerobically to check for purity. They were harvested, washed and suspended in sterile phosphate buffered saline (PBS, $p \mathrm{H} \mathrm{7.3)}$ at a concentration of $c .10^{5}$ bacteria/ml; this was used to provide the standard inoculum.

\section{Serum}

Blood $(30 \mathrm{ml})$ was drawn from 60 healthy normal adult volunteers, 20 patients with anaerobic infections and 10 patients admitted to the medical ward for reasons other than infected lesions. The blood was centrifuged at $3000 \mathrm{~g}$ for $10 \mathrm{~min}$. Serum $(c .16-20 \mathrm{ml}$ from each blood sample) was sterilised by filtration through $0 \cdot 45-\mu \mathrm{m}$ membrane filters (Millipore). The serum from each normal healthy subject was divided aseptically into three parts and stored at $-20^{\circ} \mathrm{C}$ when not used immediately. Sera from infected patients (infected sera) and sera from non-infected controls ('normal' sera) were also stored at $-20^{\circ} \mathrm{C}$ until used. Only five sera that satisfied the definition of an infected serum were used, i.e., they were obtained before administration of any antibiotics from patients from whom an anaerobic organism was isolated in pure culture (two had positive blood cultures and three post-surgical wound infections).

\section{Serum bactericidal test}

Tests to demonstrate the bactericidal activity of normal human serum were performed in three stages:

(a) Unheated serum test. Either fresh serum or one of the three parts of the frozen serum from each subject thawed only once was diluted in BM broth (Holbrook et al., 1978) containing L-cysteine hydrochloride (BDH) $0.075 \%$, to give final serum concentrations of $10 \%, 50 \%$ and $80 \%(\mathrm{v} / \mathrm{v})$ in 4-ml amounts in sterile plastic screw-capped bottles (Sterilin). Three drops of each of the bacterial suspensions were then seeded into each set of bottles and into another bottle containing plain BM broth.

(b) Inactivated serum test. A second part of the serum was inactivated in a waterbath at $56^{\circ} \mathrm{C}$ for $30 \mathrm{~min}$ and then diluted to give $10 \%, 50 \%$ and $80 \% \mathrm{v} / \mathrm{v}$ final concentrations of inactivated serum in broth. Four sets of bottles, each containing a range of the serum concentrations and plain BM broth without serum, were also seeded with corresponding bacterial suspensions as in (a).

(c) Control test with complement. The third part of the serum was inactivated as in (b) and dilutions made up in 3-ml amounts in four separate sets of bottles, each containing $10 \%, 50 \%$ and $80 \% \mathrm{v} / \mathrm{v}$ serum in BM broth. One $\mathrm{ml}$ of commercially prepared preserved guinea-pig serum complement (Wellcome Reagents Ltd, Beckenham, England) was added to each bottle. The 
haemolytic dose of complement for each of the clinical isolates was initially determined, in a pilot study, by a standard method (Mayer, 1961). Each bacterial strain was seeded into corresponding sets of bottles, into plain BM broth and into BM broths to which one haemolytic dose of complement was added.

The bottles were all incubated anaerobically (Gas-generating kit system, Oxoid) for $24 \mathrm{~h}$ at $37^{\circ} \mathrm{C}$. After incubation, the bottles were inspected for evidence of bacterial inhibition. Contents of bottles with no visible signs of growth were subcultured on to fresh blood-agar plates and incubated anaerobically.

\section{Experiments for survival of bacterial strains in serum}

The effects of serum from infected patients and 'normal' serum on the growth rate of each test strain was tested by performing viable counts after $0,4,12$ and $24 \mathrm{~h}$ in duplicate experiments. A slight modification of the procedure of Miles, Misra and Irwin (1938) was used for the tests. The sera from the infected and non-infected patients were pooled separately. Each serum pool was then divided into equal parts and each part diluted to give final concentrations of $10 \%$ and $50 \%$ $(\mathrm{v} / \mathrm{v})$ serum in broth; $0.1 \mathrm{ml}$ of each of the bacterial suspensions was then seeded into bottles containing each concentration so that the viable count of each of the test strains was performed in two concentrations of serum after $0,4,12$ and $24 \mathrm{~h}$. One anaerobic jar was used for each period to ensure continuous anaerobic incubation for the required time. At the end of the specified periods the viable count of the test strain was performed on solid medium in duplicate and the plates were incubated for a continuous period of $48 \mathrm{~h}$. Plain broth seeded with each strain was included in each jar as a control.

\section{RESUltS}

\section{Serum sensitivity and concentrations}

Table I summarises the numbers of sera from healthy subjects with bactericidal activity against each test strain at three concentrations. B. ovatus and B. vulgatus were the most susceptible strains and $B$. fragilis was the least susceptible. Each test strain grew luxuriantly in the BM broth with or without guinea-pig complement. Analysis of the overall effect of each serum on all four strains shows that the five sera that did not have any bactericidal activity against $B$. thetaiotaomicron were among the 23 that did not inhibit the $B$. fragilis strain. The remaining 18 of the 23 sera that did not inhibit $B$. fragilis inhibited the other three test strains. In no case was there bactericidal activity against any of the test strains with heat-inactivated serum at any concentration. The addition of one haemolytic dose of complement to each concentration produced results identical with those obtained in the tests with unheated sera (table II).

TABLE I

Inhibition of Bacteroides spp. by sera from healthy normal subjects

\begin{tabular}{|c|c|c|c|}
\hline \multirow{2}{*}{$\begin{array}{l}\text { Bacteroides } \\
\text { species }\end{array}$} & \multicolumn{3}{|c|}{$\begin{array}{l}\text { Number out of } 60 \text { sera that were bactericidal at } \\
\text { concentrations of }\end{array}$} \\
\hline & $10 \%$ & $50 \%$ & $80 \%$ \\
\hline $\begin{array}{l}\text { B. fragilis } \\
\text { B. vulgatus } \\
\text { B. ovatus } \\
\text { B. thetaiotaomicron }\end{array}$ & $\begin{array}{r}5 \\
46 \\
56 \\
16\end{array}$ & $\begin{array}{l}14 \\
60 \\
60 \\
44\end{array}$ & $\begin{array}{l}37 \\
\ldots \\
\ldots \\
55\end{array}$ \\
\hline
\end{tabular}


TABLE II

The bactericidal effects of normal serum, inactivated serum and complement on Bacteroides spp.

\begin{tabular}{l|ccc}
\hline \multirow{2}{*}{$\begin{array}{c}\text { Bacteroides } \\
\text { species }\end{array}$} & \multicolumn{3}{c}{ Number out of 60 sera with bactericidal activity } \\
\cline { 2 - 4 } & Normal serum & Inactivated serum & Inactivated serum $+C^{*}$ \\
\hline B. fragilis & 37 & 0 & 37 \\
B. vulgatus & 60 & 0 & 60 \\
B. ovatus & 60 & 0 & 60 \\
B. thetaiotaomicron & 55 & 0 & 55 \\
\hline \multicolumn{4}{c}{$* \mathrm{C}=$ complement }
\end{tabular}

Viable counts in serum from infected patients and 'normal' serum

The effect of serum from infected patients and 'normal' serum on the viable count of $B$. fragilis is shown in fig. 1 . After incubation for $24 \mathrm{~h}$, there was a smaller number of viable cells of $B$. fragilis in $10 \%$ and $50 \%$ 'normal' serum $\left(2.4 \times 10^{6}\right.$ and $\left.1 \times 10^{6} \mathrm{cfu} / \mathrm{ml}\right)$ than in the control broth $\left(1.5 \times 10^{7} \mathrm{cfu} / \mathrm{ml}\right)$. Conversely $B$. fragilis thrived in the sera from infected patients; after $24 \mathrm{~h}$, the viable counts were $3 \times 10^{7}$ and $2 \cdot 1 \times 10^{7}$ in $10 \%$ and $50 \%$ serum respectively.

There was a noticeably lower viable count of $B$. thetaiotaomicron in serum from infected patients than in the control broth; the reduction was less with normal serum

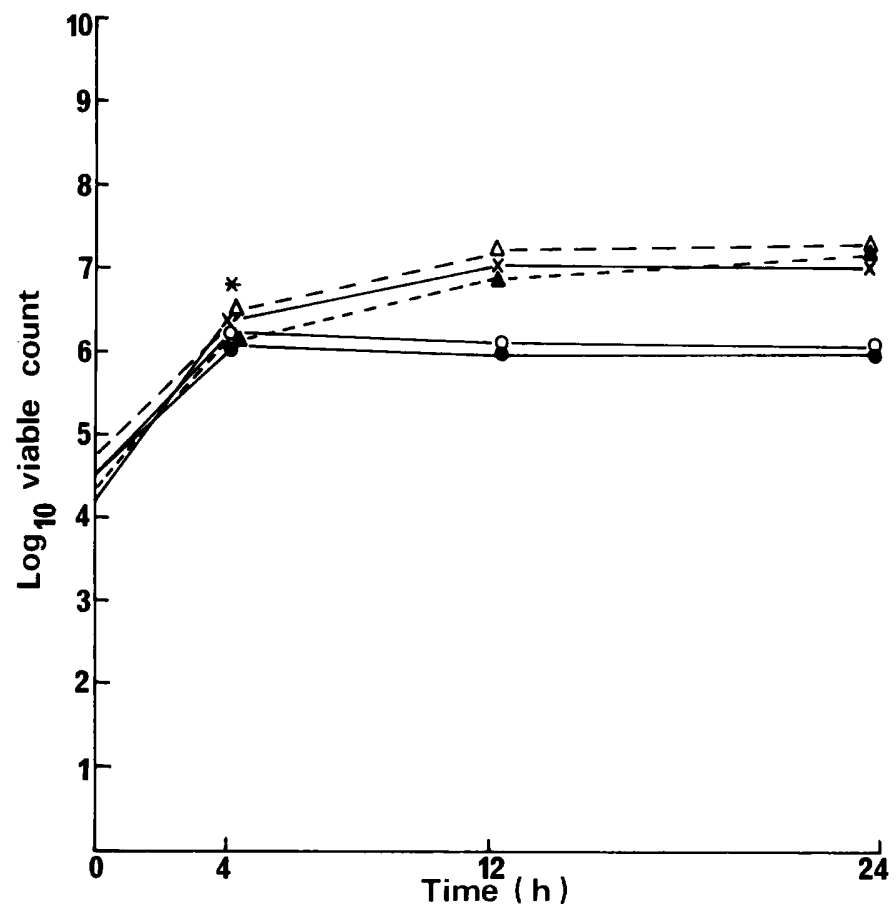

FIG. 1.-Effects of 'normal' serum and serum from infected patients on $B$. fragilis: $\bigcirc-0=10 \%$ 'normal' serum; $\longrightarrow=50 \%$ 'normal' serum; $\Delta---\Delta=10 \%$ serum from infected patients; $\Delta--\Delta=50 \%$ serum from infected patients; $\times-\times=$ control culture in BM broth without serum. 


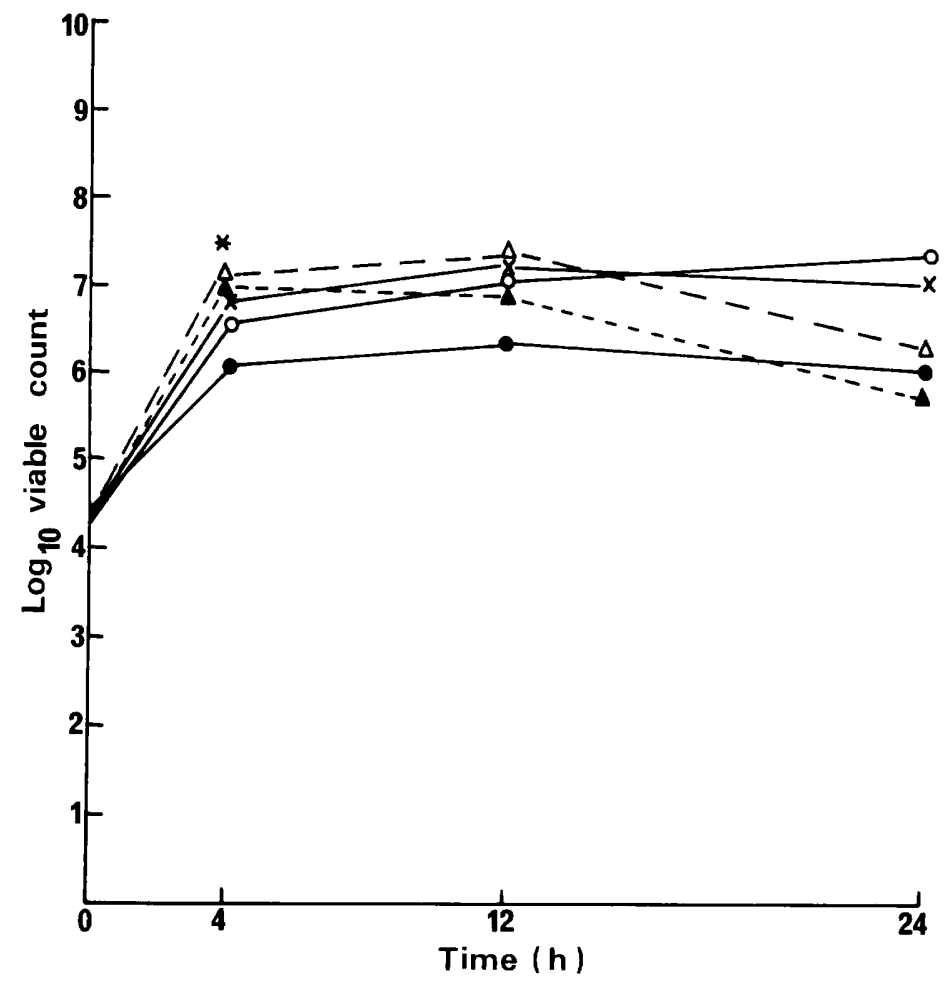

FIG. 2- Effects of two concentrations of sera from 'normal' individuals and from patients with anaerobic infection on $B$. thetaiotaomicron; for key to symbols, see caption to fig. 1 .

(fig. 2). After $24 \mathrm{~h}$, the counts were $4 \times 10^{7}$ and $1.5 \times 10^{6} \mathrm{cfu} / \mathrm{ml}$ in $10 \%$ and $50 \%$ 'normal' serum, and $4.5 \times 10^{6}$ and $7.6 \times 10^{5} \mathrm{cfu} / \mathrm{ml}$ in $10 \%$ and $50 \%$ serum from infected patients respectively; the count in the broth was $1.1 \times 10^{7} \mathrm{cfu} / \mathrm{ml}$.

The markedly lower viable counts of $B$. vulgatus in 'normal' serum and in serum from infected patients are shown in fig. 3 ; the effect of the sera was noticeable after incubation for only $4 \mathrm{~h}$. The rate of killing increased by $24 \mathrm{~h}$ when the count in broth was $1 \times 10^{8} \mathrm{cfu} / \mathrm{ml}$ compared to $1.5 \times 10^{3} \mathrm{cfu} / \mathrm{ml}$ in $50 \%$ 'normal' serum. There was a very marked bactericidal effect within $24 \mathrm{~h}$ with the serum from infected patients; the number of surviving bacteria had fallen to $4.5 \times 10^{1} \mathrm{cfu} / \mathrm{ml}$ in $10 \%$ serum and $2.1 \times 10^{1}$ $\mathrm{cfu} / \mathrm{ml}$ in $50 \%$ serum.

With $B$. ovatus the bactericidal effect increased progressively from the start to $24 \mathrm{~h}$ in both sera and this is shown in fig. 4 . After incubation for $24 \mathrm{~h}$, while the count in the broth remained high $\left(5.5 \times 10^{7} \mathrm{cfu} / \mathrm{ml}\right)$, the counts in both concentrations of the 'normal' serum and the serum from infected patients were only $5 \times 10^{3}$ and $1.6 \times 10^{3}$ $\mathrm{cfu} / \mathrm{ml}$ and $7.6 \times 10^{2}$ and $1 \times 10^{2} \mathrm{cfu} / \mathrm{ml}$ in $10 \%$ and $50 \%$ serum respectively.

\section{DisCussion}

The $B$. fragilis group forms the bulk of the anaerobic normal bacterial flora of the faeces; $B$. vulgatus and $B$. thetaiotaomicron are the predominant species (Duerden, 


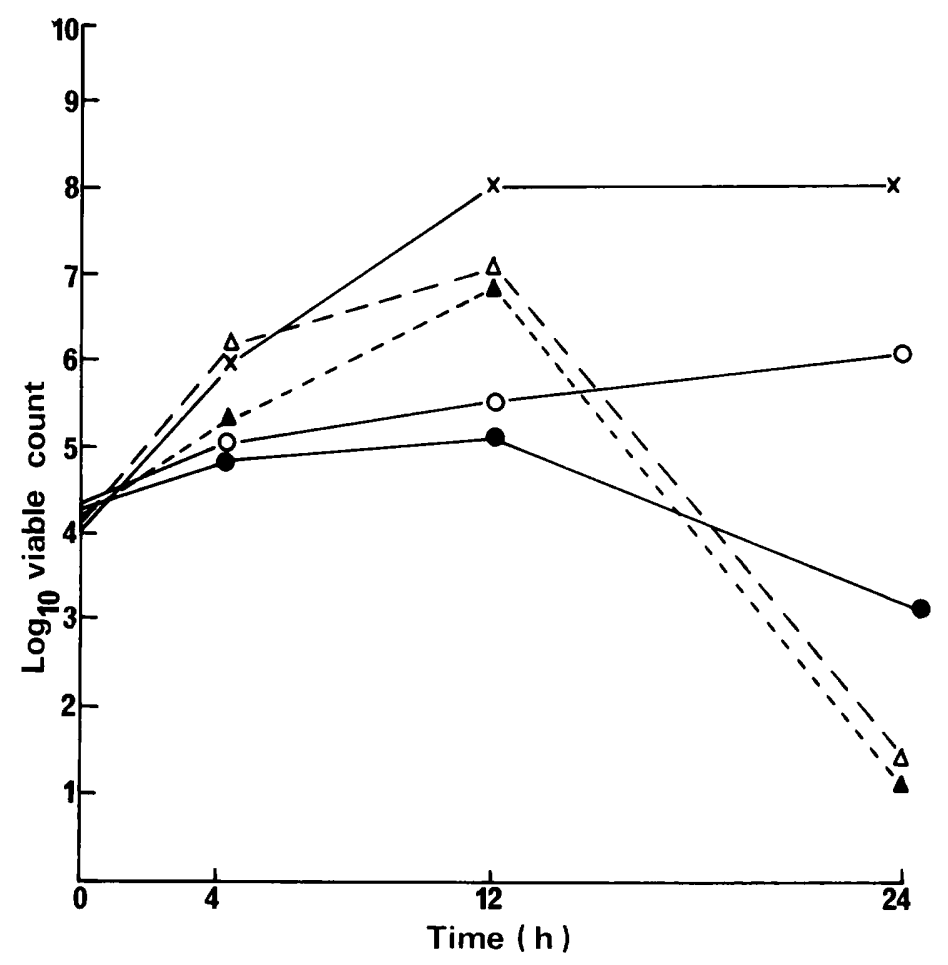

FIG. 3.-Effects of two concentrations of sera from 'normal' and infected patients on B. vulgatus; for key to symbols, see caption to fig. 1 .

$1980 a$; Rotimi and Duerden, 1981b). B. fragilis, the type-species of the group, is a less common member of the normal anaerobic flora of the faeces but is the commonest species isolated from clinical infections after abdominal or pelvic surgery (Holland et al., 1977; Duerden, 1980b).

Several reasons have been given for this. They include the possession of a polysaccharide capsule which resists phagocytosis and interferes with the phagocytosis of other bacteria (Kasper 1976; Ingham et al., 1977; Onderdonk et al., 1977), and resistance to the bactericidal action of normal human serum (Casciato et al., 1979). The results of the present study confirm and extend the findings of Casciato et al. (1979) that some clinical isolates of $B$. fragilis are not killed by human serum. Out of 60 sera tested, 23 did not inhibit the growth of the clinical isolate of $B$. fragilis. Five of these 23 sera failed to inhibit the clinical isolate of $B$. thetaiotaomicron, but all 60 sera inhibited $B$. vulgatus and $B$. ovatus at relatively low serum concentrations. Other investigations have also demonstrated bactericidal activity in normal serum against facultative gram-negative pathogens isolated from local infections but not from bacteraemic or septicaemic patients (Roantree and Rantz, 1960; Vosti and Randall, 1970; Young and Armstrong, 1972). The strains of B. thetaiotaomicron, B. vulgatus and B. ovatus that we studied were isolated from localised infections, post-surgical sepsis and an infected malignant ulcer and the $B$. fragilis was from a blood culture.

In many cases, the concentrations of the sera that inhibited the $B$. fragilis strain were higher than those that inhibited the other species. Thus, the bactericidal activity 


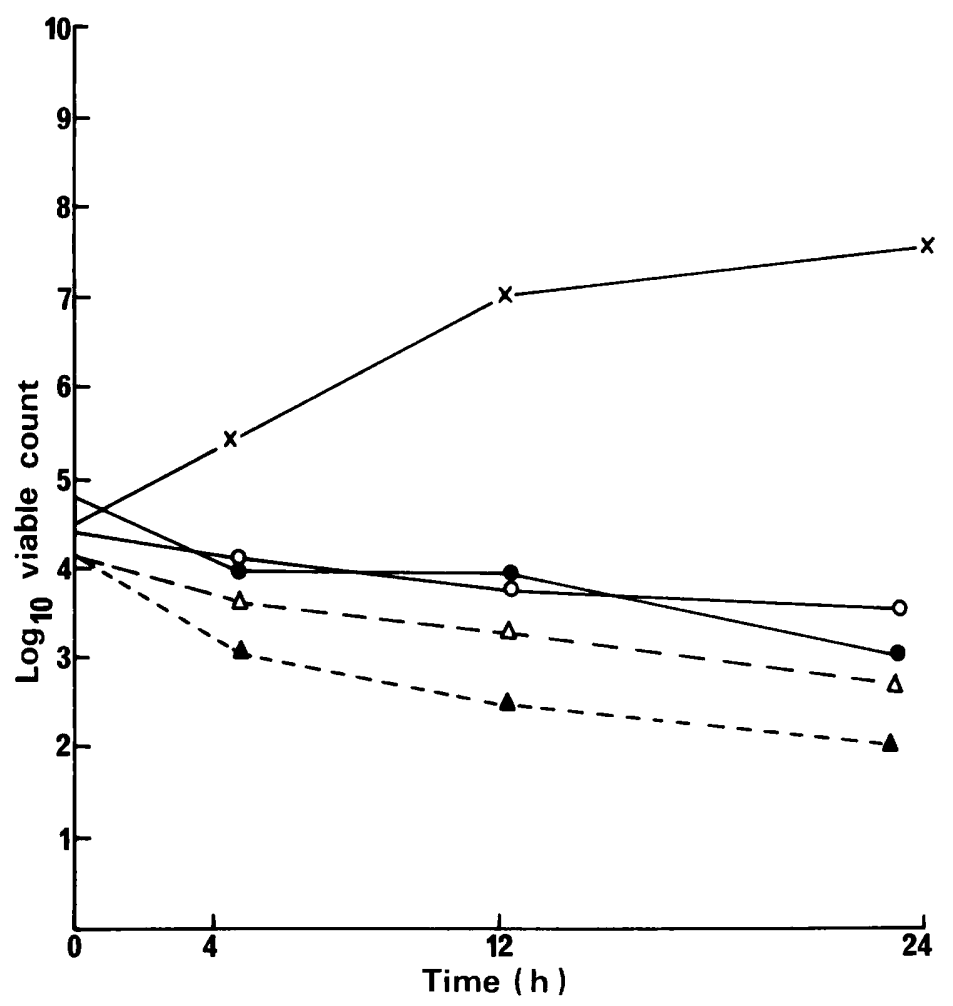

FIG. 4.-Effects of two concentrations of sera from 'normal' patients and infected patients on $B$. ovatus; for key to symbols, see caption to fig. 1 .

of serum depended upon the species of Bacteroides; the pattern of activity was nearly always the same in the sera from healthy normal individuals. The results of this study also showed that inhibitory activity depended upon heat-labile factor(s) in normal serum, and was restored to heated serum by complement. This agrees with the observation of other workers on the role of complement in lysis of gram-negative bacteria (Meshulam, Verbrugh and Werhoef, 1982).

The viable counts of the four clinical isolates in pooled serum from infected patients and in 'normal' serum were noteworthy. After incubation for $24 \mathrm{~h}$ there were significantly fewer viable bacteria of $B$. vulgatus, $B$. ovatus and, to a less extent, $B$. thetaiotaomicron in both sera than in control broths; bactericidal activity was clearly demonstrated against $B$. vulgatus and $B$. ovatus. In all cases except with $B$. fragilis, the serum from infected patients was more inhibitory than the 'normal' serum at both concentrations. B. fragilis was relatively unaffected; its count was higher in the serum from infected patients than in the broth after incubation for $24 \mathrm{~h}$. This indicates that the susceptibility of individual Bacteroides spp. to the bactericidal activity of human serum is related to the source of the serum.

Most normal human sera from all age groups contain circulating humoral antibody of the IgM and IgG classes to Bacteroides spp. of the normal bacterial flora (Quick, Goldberg and Sonnenwirth, 1972; Hofstad, 1974; Kasper, 1976). Although 
the present study did not provide any evidence that these types of antibodies may be involved in the bactericidal action of normal serum and serum from infected patients, it showed that heat-labile components of human serum (Muschel, 1960), and perhaps other factors, are essential for the inhibition of all serum-sensitive Bacteroides spp.

Serum bactericidal capacity is probably an important host-resistance factor against systemic invasion by organisms of the $B$. fragilis group other than its type species, $B$. fragilis, which possesses the ability to multiply in serum from infected patients and other virulence factors, such as a capsule (Kasper, 1976; Onderdonk et al., 1977; Polk and Kasper, 1977). The relative resistance and viability of $B$. fragilis in serum may partly explain its pathogenic potential and predominance over other species in serious clinical infections despite its minor contribution to the normal anaerobic bacterial flora.

This study was partly supported by a Research Grant from the College of Medicine of University of Lagos. We thank Mrs Marilyn Cole and Mrs Lillian Bryson for their secretarial assistance.

\section{REFERENCES}

Bartlett J G, Finegold S M 1972 Anaerobic pleuro-pulmonary infections. Medicine 51:413-450. Casciato D A, Rosenblatt J E, Goldberg L S, Bluestone R 1975. In vitro interaction of Bacteroides fragilis with polymorphonuclear leukocytes and serum factors. Infection and Immunity $11: 337-342$.

Casciato D A, Rosenblatt J E, Bluestone R, Goldberg L S, Finegold S M 1979 Susceptibility of isolates of Bacteroides to the bactericidal activity of normal human serum. Journal of Infectious Diseases 140:109-113.

Drasar B S, Shiner M, McLeod G M 1969 Studies on the intestinal flora. I. The bacterial flora of the gastrointestinal tract in healthy and achlorhydric patients. Gastroenterology 56:71-79.

Duerden B I $1980 a$ The isolation and identification of Bacteroides spp. from the normal human faecal flora. Journal of Medical Microbiology 13:69-78.

Duerden B I $1980 b$ The identification of gram-negative anaerobic bacilli isolated from clinical infections. Journal of Hygiene 84:301-313.

Duerden B I, Collee J G, Brown R, Deacon A G, Holbrook W P 1980 A scheme for the identification of clinical isolates of gram-negative anaerobic bacilli by conventional bacteriological tests. Journal of Medical Microbiology 13:231-245.

Felner J M, Dowell V R 1971 "Bacteroides" Bacteremia. American Journal of Medicine 50: 787-796.

Gorbach S L, Bartlett J G 1974 Anaerobic infections. New England Journal of Medicine 290: $1177-1184$.

Hofstad T 1974 Antibodies reacting with lipopolysaccharides from Bacteroides melaninogenicus, Bacteroides fragilis and Fusobacterium nucleatum in serum from normal human subjects. Journal of Infectious Diseases 129:349-352.

Holbrook W P, Ogston S A, Ross P W 1978 A method for the isolation of Bacteroides melaninogenicus from the human mouth. Journal of Medical Microbiology 11:203-207.

Holland J W, Hill E O, Altemeier W A 1977 Numbers and types of anaerobic bacteria isolated from clinical specimens since 1960. Journal of Clinical Microbiology 5:20-25.

Ingham H R, Sisson P R, Tharagonnet D, Selkon J B, Codd A A 1977 Inhibition of phagocytosis in vitro by obligate anaerobes. Lancet $2: 1252-1254$.

Kasper D L 1976 The polysaccharide capsule of Bacteroides fragilis subspecies fragilis: immunochemical and morphologic definition. Journal of Infectious Diseases 133:79-87.

Masfari A N, Kinghorn G R, Duerden B I 1983 Anaerobes in genitourinary infections in man. British Journal of Venereal Diseases 59:255-259.

Mayer M M 1961 Complement and complement fixation. In: Kabat E A, Mayer M M (eds) Experimental immunochemistry, 2nd edn, Charles C. Thomas, Springfield, pp 133-149. 
Meshulam T, Verbrugh H, Verhoef J 1982 Serum-induced lysis of Pseudomonas aeruginosa. European Journal of Clinical Microbiology 1:1-6.

Miles A A, Misra S S, Irwin J O 1938 Estimation of the bactericidal power of blood. Journal of Hygiene 38:732-749.

Muschel L H 1960 Serum bactericidal actions. Annals of New York Academy of Sciences $88: 1265-1272$.

Onderdonk A B, Kasper D L, Cisneros R L, Bartlett J G 1977 The capsular polysaccharide of Bacteroides fragilis as a virulence factor: comparison of the pathogenic potential of encapsulated and unencapsulated strains. Journal of Infectious Diseases 136:82-89.

Polk B F, Kasper D L 1977 Bacteroides fragilis subspecies in clinical isolates. Annals of Internal Medicine 86:569-571.

Quick J D, Goldberg H S, Sonnenwirth A C 1972 Human antibody to Bacteroidaceae. American Journal of Clinical Nutrition 25:1351-1356.

Roantree R J, Rantz L A 1960 A study of the relationship of the normal bactericidal activity of human serum to bacterial infection. Journal of Clinical Investigation 39:72-81.

Roberts R B 1970 The relationship between group A and group C meningococcal polysaccharides and serum opsonins in man. Journal of Experimental Medicine 131:499-513.

Rotimi V O, Duerden B I 1981 $a$ The development of the bacterial flora in normal neonates. Journal of Medical Microbiology 14:51-62.

Rotimi V O, Duerden B I $1981 b$ Bacteroides species in the normal neonatal faecal flora. Journal of Hygiene 87:299-304.

Rotimi V O, Abudu O O Anaerobes in septic abortion. West African Journal of Medicine (In press).

Rotimi V O, Faulkner J, Duerden B I 1980 Rapid methods for the identification of clinical isolates of gram-negative anaerobic bacilli. Medical Laboratory Sciences 37:331-339.

Sinkovics J G, Smith J P 1970 Septicaemia with Bacteroides in patients with malignant disease. Cancer 25:663-671.

Vosti K L, Randall E 1970 Sensitivity of serologically classified strains of Escherichia coli of human origin to the serum bactericidal system. American Journal of Medical Sciences 259:114-119.

Williams R C 1972 Opsonins in phagocytosis. In: Williams R C, Fundenberg H H (eds) Phagocytic mechanisms in health and disease, Intercontinental Medical Book Corp., New York, pp 167-179.

Young L S, Armstrong D 1972 Human immunity to Pseudomonas aeruginosa. I. In vitro interaction of bacteria, polymorphonuclear leukocytes and serum factors. Journal of Infectious Diseases 126:257-276. 